\title{
Clinical and functional effectiveness of anti-TNF therapy in patients with rheumatoid arthritis
}

Rosalia Martínez-Pérez*, Julia Uceda, Mario León, Sergio Rodríguez, Alejandro Muñoz, Francisco Gallo, Maria Luisa Velloso, Jose Luis Marenco

From 6th European Workshop on Immune-Mediated Inflammatory Diseases

Nice, France. 23-25 November 2011

\section{Objective}

To evaluate the clinical and functional activity of patients with rheumatoid arthritis at one and two years after starting anti-TNF therapy.

\section{Patients and methods}

This is a retrospective study of 50 RA patients, who started ANTI-TNF theraphy between June 2006 and july 2009. The main variables in the study were: DAS28, HAQ and pain VAS. We analyzed evolution after 1 year and 2 years from the beginning of the treatment. The comparison with the basal state was made with Student's $t$ test. The statistical study was analyzed by the SPSS 18,0 .

\section{Results}

The study includes 50 patients, $66 \%$ female, with RF in $76 \%$ and erosions in $64 \%$, treated with etanercept (28), adalimumab (13) and infliximab (9). Most of them (70\%) had recieved at least 2 FAMES before biological. In the below table we compare changes in clinical parameters for different biologics after one and two years.

\section{Conclusions}

All anti-TNF significantly improve disease activity, functional status and pain VAS after the first year. This improvement continues but not significantly increases the second year.

Table 1

\begin{tabular}{llll}
\hline & BASAL & $\mathbf{1 2}$ MONTHS $(\boldsymbol{p}$ basal-12M) & 24 MONTHS (p 12M-24M) \\
\hline EVA (mm) & & \\
-Etanercept & $72,21 \pm 16,78$ & $33,20 \pm 20,05(p<0,005)$ & $31,95 \pm 27,12(p=0,39)$ \\
-Adalimumab & $69,83 \pm 20,54$ & $45,00 \pm 28,33(p=0,21)$ & $51,00 \pm 28,44(p=0,16)$ \\
-Infliximab & $69,78 \pm 15,45$ & $42,56 \pm 23,41(p=0,015)$ & $37,71 \pm 23,95(p=0,86)$ \\
\hline DAS28 & & \\
-Etanercept & $5,88 \pm 1,05$ & $2,85 \pm 1,16(p<0,005)$ & $3,09 \pm 1,52(p=0,98)$ \\
-Adalimumab & $5,73 \pm 1,51$ & $4,05 \pm 2,43(p=0,011)$ & $3,90 \pm 1,88(p=0,22)$ \\
-Infliximab & $6,03 \pm 1,87$ & $4,08 \pm 1,61(p=0,021)$ & $3,83 \pm 1,66(p=0,91)$ \\
\hline HAQ & & \\
-Etanercept & $1,61 \pm 0,61$ & $0,77 \pm 0,64(p<0,005)$ & $1,38 \pm 0,70(p=0,58)$ \\
-Adalimumab & $1,63 \pm 0,58$ & $1,35 \pm 0,63(p=0,05)$ & $1,28 \pm 0,69(p=0,34)$ \\
-Infliximab & $1,45 \pm 0,74$ & $1,24 \pm 0,72(p=0,20)$ &
\end{tabular}

Rheumatology Unit, Valme University Hospital, Sevilla, Spain

(c) 2011 Martínez-Pérez et al; licensee BioMed Central Ltd. This is an open access article distributed under the terms of the Creative 
Etanercept is the only drug with a significant reduction for HAQ, DAS28 and pain VAS.

Published: 23 November 2011

doi:10.1186/1479-5876-9-S2-P46

Cite this article as: Martínez-Pérez et al: Clinical and functional

effectiveness of anti-TNF therapy in patients with rheumatoid arthritis.

Journal of Translational Medicine 2011 9(Suppl 2):P46.

Submit your next manuscript to BioMed Central and take full advantage of:

- Convenient online submission

- Thorough peer review

- No space constraints or color figure charges

- Immediate publication on acceptance

- Inclusion in PubMed, CAS, Scopus and Google Scholar

- Research which is freely available for redistribution

Submit your manuscript at 